\title{
Kalevalamittaisen runonlaulun rytmilaeista II
}

Kalevalamittaisen runonlaulun musiikillisen rytmin perustana on yhtä (periodisesti toistuvaa) rakenneyksikköä vastaava rytmikuvio, joka koostuu pitkistä ja lyhyistä kestoista. ${ }^{1}$ Tällä tasolla sävelrytmi yhdistyy säerakenteeseen; konkreettinen rytmi ja konkreettinen säe saattavat poiketa siitä enemmässä tai vähemmässä määrin. Lyhyt ja pitkä kesto ovat kaksi eri kategoriaa, mutta niillä ei ole tarkkoja kestosuhteita. Tällainen rytmikuvio on alisteinen koristelulle, tietyille musiikillisille mutaatioille sekä konkreettisten säkeiden prosodisista erikoispiirteistä johtuville muutoksille.

Artikkelin ensimmäisessä osassa tarkasteltiin sitä Euroopan keskiajan musiikinhistorian kautta, jolloin nuottien kestoja alettiin merkitä. 1200-luvulla kehittynyt modaalirytmiikka käsittää monia teoreettisia periaatteita, joita voi käyttää kalevalamittaisten laulujen rytmianalyysissa: pitkistä ja lyhyistä kestoista muodostuvat kuviot (modus, ordo) ja niiden transformaatiosäännöt. Tuonaikainen opetus lähti ensisijassa siitä, että rytmikuvion on yhdistettävä runonsäe ja melodia. Kalevalamittaisessa laulussa tilanne on periaatteessa samanlainen, mutta itse rytmikuviot ovat toisenlaisia. 


\section{Runonlaulun rytmilait}

Siirrymme nyt runolaulujen rytmiikan erittelyyn. Pohdinnan kulmakivenä on siis se, että kaikki skemaattiset rytmikuviot koostuvat lyhyistä ja/tai pitkistä kestoista; niiden tarkat kestosuhteet eivät ole niin tärkeitä, kunhan ne eroavat ryhminä selvästi toisistaan. Edelleen olisi syytä pohtia, miten rytmikuvioita on tarkasteltava.

Runonlaulun keskeisenä rakenneyksikkönä on säe samalla tavalla kuin eurooppalaisessa keskiaikaisessa lauluperinteessä yleensäkin. Sanat eivät muodosta vakiorakenteisia säeryhmiä - säkeistöjä. Laulettaessa kuitenkin syntyy poikkeuksellisesti joskus säeryhmä. Tätä ei kuitenkaan tarvitsisi lähemmin tarkastella, koska se on perinteen rapistumista, uusien muotojen vaikutusta, mutta emme ohita ilmiötä kokonaan. Runonlauluperinteessä esilaulajan laulamaa säettä toisti tavallisesti kuoro tai toinen laulaja. Laulaessaan yksin lauluja, joissa on kaksirivisiä sävelmiä, esittäjä pyrkii usein etenemään nopeammin eikä toista säkeitä, ja näin sävelmätoistojen yhteydessä syntyy myös säepareja. Nämä eivät tosin ole muodoltaan tarkoin määräisiä yksiköitä, mutta monet laulajat yrittävät toimia siten, että sävelmän jälkimmäiseen riviin osuisi runon rinnakkaissäe ja että uusi ajatus, uusi runonsäe, alkaisi aina sävelmän ensimmäisestä rivistä. Näin on asianlaita myös nelirivisten sävelmien kohdalla; ne lienevät uudempia ja soveltuvat huonommin perinteiseen esilaulajan ja kuoron vuorotteluun. Syntyviä nelirivisiä säeryhmiä ei saa missään tapauksessa pitää säkeistöinä.

Säe voi jakautua säepuoliskoihin, mutta varmasti se jakautuu runojalkoihin tai painoryhmiin. Tästä syystä meitä kiinnostavat eniten säkeen mittaiset rytmikuviot ja sitä pienemmät yksiköt. Juuri näissä rajoissa tekstiyksiköt sovitetaan yhteen sävelmän kanssa - muistelkaamme Guido Arezzolaisen käsitystä rytmistä. ${ }^{2}$

\section{Aineisto}

Havainnollistaakseni näkökulmaani olen analysoinut kolme laajaa sävelmäkokoelmaa, joissa on julkaistu itämerensuomalaisten kansojen runolaulua: Armas Launiksen Inkerin runosävelmät ja Karjalan runosävelmät (Suomen kansan sävelmiä IV, 1. ja 2. osa; Helsinki 1910 
ja 1930), sekä Herbert Tamperen Eesti rahvalaule viisidega I-V (Tallinna 1956-65). Vatjalaisia sävelmiä oli Launiksen teoksessa vähän, mutta tämän pienen kansan säilyneistä sävelmistä on Ingrid Rüütel laatinut kokoavan yleiskatsauksen (Rüütel 1977). Koko aineisto käsitti 2359 sävelmää - 602 virolaista, 74 vatjalaista, 750 inkerinmaalaista sekä 794 karjalaista.

On erittäin vaikea sanoa, millaista osaa olemassaolevista runosävelmistä ne edustavat. Arkistojen kortistot kuvailevat jokaista nuotinnosta tai ääninauhaa, ja niiden joukossa on paljon samalla sävelmällä laulettuja lauluja ja niiden läheisiä ja kaukaisempia toisintoja. Runolauluista on usein mahdotonta sanoa, mihin yhden sävelmän toisinto loppuu ja mistä alkaa uusi. Vasta kun kaikki sävelmät on toimitettu julkaisukuntoon, voi tarkasti sanoa, minkälainen tähän mennessä julkaistu osa todellisuudessa on. Luultavasti siihen menee vielä runsaasti aikaa, ja toistaiseksi meidän täytyy tyytyä vain olettamuksiin.

Olen kuunnellut noin kaksi kolmasosaa KM RO: $n^{3}$ nauha-arkiston runosävelmänauhotteista (ennen vuotta 1976 tehdyt äänitteet). Tämän perusteella olen saanut vaikutelman, että todella erilaisia sävelmiä voi Virossa olla vain satoja, ei tuhansia. Herbert Tampere on kirjansa sävelmiä valitessaan pitänyt erittäin hyvin huolta, että edustettuna olisivat sekä eri alueet että erilaiset musiikin ilmiöt. Launiksen teosten periaate on toinen: hän on koettanut julkaista kaiken ulottuvillaan olevan aineiston, ja hänen kirjansa sisältääkin huomattavan osan SKS: $n^{4}$ käsikirjoitusten pohjalta kootusta runosävelmien (kalevalasävelmien) kortistosta. Myöhemmissä karjalaisen ja inkeroisaineiston kokoelmissa (SKS, KM RO, $\mathrm{KKI}^{5}$, Petroskoi ym.) ei ole tarkkoja tietoja runosävelmistä. Nauhoja on paljon, mutta kuinka paljon on löydetty uusien toisintojen ryhmiä? Kun ottaa huomioon perinteen luonteen voi arvella, samoin kuin Viron aineistonkin suhteen, että Launiksen julkaisemat 700-800 sävelmää kummaltakin alueelta ovat musiikillisten ilmiöiden tutkimiseksi ehkä sopiva määrä.

Pelkästään kirjoitetun aineiston pohjalta ei tietenkään voi tehdä päätelmiä rytmikuvioiden rakenteesta, mutta tätä aineistoa analysoidessani minulla oli tukena satojen runonlauluäänitteiden nuotintamisesta saatu kokemus. Useimmat vanhempaan aineistoon perustuvat rytmikaavat on myös nauhoitettu monina versioina vuosina 1950-70, ja kokemus niiden kuuntelusta antaa vankan pohjan myös vanhempien nuotinnoksien tulkitsemiseksi. Mutta on monia jännittäviä rytmikuvioita, joita ei enää nauhakeruun aikaan esiintynyt. Jos ta- 
paamme samaa rytmiä monista lauluista, eri kerääjien muistiinpanemina, ei ole syytä epäillä rytmin todellista olemassaoloa. Sen sijaan rytmikuvioksi ei voi laskea yksityistä epätavallisella rytmillä nuotinnettua laulua.

Tässä on tarkasteltu ainoastaan sävelmärivien rytmikuviota, ei kertosäettä. Mukaan ei ole otettu yleisestä runolaulujen muodosta poikkeavia alaperinteitä, kuten itkuja, lastenlauluja, setukaisten lauluja (niiden moniäänisyys sekä tapa lisätä tavuja säkeeseen vaativat erilaista lähestymistapaa) sekä venäläisittäin venytettyjä inkeroislauluja.

\section{Runojalan rytmi}

Tarkastelemme aluksi runojalkaa vastaavia rytmikuvioita, joskin sanojen erilaiset ryhmittymät usein peittävät tai sekoittavat kokonaan yksityisiä runojalkoja. Kahdesta kestosta, lyhyestä (brevis = B) ja pitkästä (longa $=\mathrm{L}$ ), voi muodostaa neljä erirytmistä runojalkaa, ja kaikkia myös todella esiintyy: BB, runonlaulun levinnein rytmi; LB, yleinen Suomessa, Virossa harvinainen; BL, yleinen Virossa, muualla harvinaisempi; sekä LL, karjalais- ja inkeroislaulujen viimeisessä runojalassa, inkeroislauluissa myös ensimmäisessä (esim. 1).

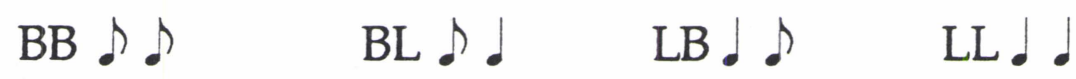

Näistä rytmikuvioista kolme ensimmäistä voivat hallita koko runoa, mutta viimeinen ei (mainitun perinteenmukaisen keskinäisen järjestyksen vuoksi).

Runolauluperinnettä luonnehtii yhtäläinen, lyhyistä kestoista koostuva rytmi. Suomessa yleistynyt viimeisen runojalan laajentaminen (LL) ei muuta asiaa, se on eräänlainen lopukemuodostelma. Yhtäläisessä rytmissä ei myöskään ole mitenkään korostettu rytmien liitoskohtia eikä runopuoliskojen rajaa, ja se mahdollistaa runomitalla leikittelyn silloin kun runossa on erilaisia painoryhmittymiä $(3+3+2$, $3+2+3,2+3+3$ tavua jne.).

Voitaisiin myös ajatella, että rytmin BL olemassaolo jo sinänsä todistaa rytmin tietystä autonomisuudesta. Runonlaulun säkeessä yleensä vältetään lyhyen tavun osumista runojalan nousuun (pitkälle osalle). Eduard Laugaste (1977: 144) selittää tätä seuraavasti: "[...] sillä osuessaan säepainolliseen kohtaan ei pääpaino muutu sel- 
vemmäksi, vaan lyhyt vokaali pidentyy olennaisesti (sen kesto muuttuu), ja sen myötä muuttuu joskus myös sanan merkitys [...]." Muulloin tämä pitää paikkansa, mutta ei runoa laulettaessa. Jos sanan merkitys muuttuu (jos joku ymmärtää asian niin), syynä voi olla ainoastaan tavun väärä sijainti säkeessä, virhe vakiintuneen normin suhteen.

Ilse Lehiste väittää, ettei tämä sääntö ole yhtä ankara lyhyiden pääpainollisten tavujen kuin pitkien suhteen (Lehiste 1973). Lyhyelle alkutavulle paino antaa kuitenkin tiettyä korostusta, jota runojalan nousussa tarvitaan; pitkä pääpainollinen tavu runojalan laskussa rikkoo rytmiä ilmeisesti liiaksi. Runonlaulun musiikillinen rytmi ei voi vääristää kielen prosodiaa, sen voivat tehdä ainoastaan myöhemmin lainatut rytmit (ks. näytettä kansanomaisesta laulusta artikkelin ensimmäisessä osassa, Lippus 1990: 103). Näin voinemme löytää Viroon levinneelle ja täysin normaalille BL-rytmille luonnollisen selityksen.

Vaikka sanojen kestojärjestelmän olemuksesta on kiistelty paljon, ovat foneetikot ja fonologit samaa mieltä siitä, että kesto ei riipu ainoastaan äänteiden pituudesta ja tavujen pituuksien suhteesta (ks. Eek 1987). Tavurakenteiden oikean hahmottamisen kannalta on pääpainollisen tavun pituus ja rakenteelle ominainen intonaatio tärkeämpää kuin segmenttien absoluuttiset pituudet sekä niiden suhteet. Laulun jälkitavun venyttäminen ei ole enää tärkeää, jos pääpainollinen tavu on pantu runojalan nousun korosteiseen asemaan. Vielä vaivattomammin siirtyvät sekä runon että musiikin rytmissä yksitavuiset sanat ja kolmitavuisten sanojen lopputavut. Riippumatta omasta äännerakenteestaan ne täyttävät tarpeen vaatiessa joko lyhyen tai pitkän tavun paikkaa: "Kuului kuutehen kylähän, seittemen selän ylitsi," tai: "Sai see vene vestetusta, kaabitust' sai laiva kaasi." 6

Vielä mutkikkaampi on kysymys, miksi emme havaitse tässä rytmissä myös lyhyiden pääpainollisten tavujen (enimmäkseen runojalan laskussa, siis BL-rytmistä venytettyjen) erityistä vääristymistä. Esimerkiksi Jolähtmen kunnan (Pohjois-Viron rannikolla) keinulaulun runossa "Kui ei kanna, siis kadugu"7 on 6. tavu ka- keinumisen rytmissä venytetty erittäin pitkäksi; samasta laulusta vielä "kardavad kullad kuluma"8, "oues on obedaseppad, taras on rahatagujad"9 (kuluma ja kuuluma ovat kestoasteen mukaan jopa erimerkityksisiä sanoja). Varmasti tässä auttaa kyky tasapainottaa painotuksen siirtoa runossa silloin kun pitkän ja lyhyen tavun vaihtuminen sekä painoryhmien alut eivät täsmää. Tavunuotissa selkeästi erottuvat painorakenteen osat 
ovat hajallaan, ja tajuamme tekstin ja musiikin kahdeksi itsenäiseksi järjestelmäksi. Koska tavun asema on musiikillisesti painoton, ei vääristelevä venyttäminen juurikaan pistä silmään.

\section{Puolisäkeen rytmi}

Puolisäe toimii selvästi itsenäisempänä musiikillisena kuviona kuin neljä alkuosaa tai kaksi runojalkaa. Puolisäkeiden välinen sesuura (tauko) erottuu perinteessä selkeästi kokonaisuudeksi (nelitavuista sanaa ei koskaan aseteta säkeen keskelle), vaikka se painosiirtoisissa (kolmitavuiset sanat tai sanaryhmät) säkeissä jää varjoon tai siirtyy keskeltä pois. Puolisäe voi toistua musiikillisena kuviona - on sävelmiä, jotka koostuvat vain saman motiivin toistosta, mutta alkurivin motiivin toistoa löydämme enemmän kaksisäkeisisten runojen jälkisäkeestä (esim. 2).

$$
\text { A -> aa, } \quad A B->\text { abac, abcb, abbc jne. }
$$

Usein tapaamme myös painosiirtoisista sävelmävarianteista pyrkimyksen säilyttää puolisäkeen sävelkuvioita - esimerkiksi alkuosan $4+4$ sisältänyt sävelmä muuttuu: alkuosa $5+3(2+3+3$ tai $3+2+3)$ venyttää hieman ensimmäisen puolisäkeen kuviota ja lyhentää toisen kuviota, jotta sävelmän keskiosa siirtyisi varsinaiselle sesuuralle (Lippus 1984).

Neljästä runojalan rytmistä on periaatteessa mahdollista muodostaa 16 puolisäekuviota ja niitä on todella olemassa, joko molempien puolisäkeiden tai toisen puolisäkeen kuviona (esim. 3; tähdellä * merkitään sellaisia johdettuja kuvioita, joita näistä lauluista ei löytynyt):

\begin{tabular}{|c|c|}
\hline $\mathrm{BB}+\mathrm{BB}$ & - laajalti levinnyt \\
\hline LL+LL & - 2. motiivina joissakin yksityisissä virolaisissa lauluissa \\
\hline $\mathrm{BB}+\mathrm{BL}$ & - laajalti levinnyt, erityisesti 2.motiivina; \\
\hline $\mathrm{LB}+\mathrm{BB}$ & $\begin{array}{l}\text { - 1. motiivina yksityisissä lauluissa, mahdollisesti } \\
\text { satunnainen agoginen venytys; }\end{array}$ \\
\hline $\mathrm{BB}+\mathrm{LB}$ & $\begin{array}{l}\text { - 1. motiivina inkerois- ja karjalaislauluissa, harvoin myös } \\
\text { toisena motiivina; }\end{array}$ \\
\hline $\begin{array}{l}+\mathrm{LB}^{*} \\
\mathrm{~B}+\mathrm{LL}\end{array}$ & - laajalti levinnyt; \\
\hline
\end{tabular}


LL+BB - 1. motiivina inkeroislauluissa, joskus myös 2. motiivina;

$\mathrm{BL}+\mathrm{BL} \quad$ - levinnyt virolaisiin, vatjalaisiin, inkerois-, harvoin myös karjalaislauluihin;

LB+LB - levinnyt karjalais- ja inkerois-, harvoin myös virolaislauluihin;

$\mathrm{LB}+\mathrm{BL} \quad$-2. motiivina karjalaisissa lauluissa $B L+\mathrm{LB}^{*}$

$L B+L L$

- 2. motiivina karjalaisissa- ja inkeriläisissä lauluissa.

$\mathrm{LL}+\mathrm{BL}^{*}$

$L L+L^{*}$

$B L+L^{*}$

\begin{tabular}{|c|c|c|c|c|c|}
\hline$B B+B B$ & $\partial \phi \lambda$ & $B B+L L$ & 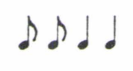 & $\mathrm{BL}+\mathrm{LB}^{*}$ & $(\phi \perp d \phi)$ \\
\hline$L L+L L$ & d d d & $L L+B B$ & $\partial D$ & $\mathrm{LB}+\mathrm{LL}$ & $d \rho d$ \\
\hline$B B+B L$ & $D D D$ & $\mathrm{BL}+\mathrm{BL}$ & $D d D$ & $L L+B L^{*}$ & 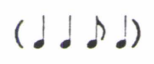 \\
\hline $\mathrm{LB}+\mathrm{BB}$ & $\partial \phi \lambda$ & $\mathrm{LB}+\mathrm{LB}$ & 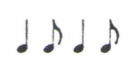 & $\mathrm{LL}+\mathrm{LB}^{*}$ & (\lrcorner$\cdot d \cdot)$ \\
\hline $\mathrm{BB}+\mathrm{LB}$ & 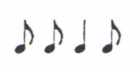 & $L B+B L$ & 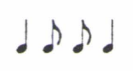 & $\mathrm{BL}+\mathrm{LL}^{*}$ & $(\partial d \cdot)$ \\
\hline
\end{tabular}

Voitaisiin hieman pohtia niitä viittä rytmikuviota, joita tästä aineistosta ei löytynyt. Olisivatko ne mahdollisia? En ole yhdestäkään löytänyt todisteita, että se olisi esimerkiksi runon suhteen täysin mahdoton. Onhan muita päällisin puolin mahdottomia olemassa, ja koska niitä tosiaan on, löydämme toki syitä, miksi ne eivät ole ainoastaan mahdollisia vaan aivan luonnollisia. Ainakin voisi selittää, miksi nämä viisi kuviota ovat epätodennäköisiä.

Miksi rytmi BLLL puuttuu, vaikka LBLL on olemassa? Rytmi LBLL on kotoisin Karjalasta, jossa on tapana venyttää viimeistä runojalkaa, jos runossa on samanlaisista kestoista muodostuva rytmi. Jos nyt LBrytmisten runojen viimeistä jalkaa venytetään, tulee rytmiksi LBLB LBLL. Rytmiä BL on muuten tavattu enimmäkseen Virosta, jonkin verran myös vatjalaisista ja inkeroislauluista. Virossa on kyllä viimeisen runojalan venyttäminen kadenssimuodossa tunnettu, mutta ei muodossa $L L$ vaan $B L$ - näin voi siis rytmistä BL kehittyvä rivi *BLBL BLLL jäädä syntymättä. On sitä paitsi mahdollista, että se hidastaisi liikettä, onhan LLLL säkeen toisena motiivina aika harvinainen. 
Sen, että rytmikuvioita BLBB ja BLLB ei tavata, yhdistäisin toisen elementin epäsymmetriseen esiintymiseen - sekä ensimmäisen että kolmannen runojalan laskut ovat luonteeltaan runon vähiten esiinpistäviä elementtejä (toisen ja erityisesti neljännen runojalan laskun venyttämisellä on musiikissa sesuuran tehtävä). Ja kannattaa panna merkille, että juuri rivinloppuja pyritään venyttämään; silloin olisi kuvioissa LLBL ja LLLB lyhyt kesto liian yksinäisenä säkeen lopussa. Nämä selitykset ovat kuitenkin kaikki semmoisia, että tosielämä voi ne kumota (vaikka en voi uskoa näiden viimeksi mainittujen kuvioiden luonnollisuuteen).

\section{Säkeen rytmi}

Teoreettisia mahdollisuuksia säkeen rytmikuvion muodostamiseen olisi jo $16 \times 16=256$, mutta todella olemassa olevista puolisäkeen kuvioista $11 \times 11=121$.

Todellisuudessa on olemassa vain 22 rytmikuviota, näistäkään neljää ei suoraan (näistä contraction eli tiivistämisen avulla kuvattavista rytmeistä puhumme vielä hiukan enemmän). Seuraavaa rytmikuvioiden luetteloa ei tarvitse pitää lopullisena. Todennäköistä on ainoastaan, että kuvioita tulisi korkeintaan kymmenkunta lisää, jos voitaisiin käydä läpi kaikki olemassaolevat runosävelmät. Luvuista näkyy tietenkin sävelmien määrä ja vastaava rytmi sekä prosenttiosuus analysoidusta aineistosta. Kokemukseni virolaisten runosävelmien analysoimisesta osoittaa, että kun aineisto ylittää 400-500 sävelmän rajan ja ne on valittu enemmän tai vähemmän koko Virosta, niin eri ilmiöiden osuudet aineistokokonaisuudesta rupeavat vakiintumaan. Yhtä ja samaa rytmikuviota lauletaan tietysti monilla sävelmillä, mutta myös yksi ja sama sävelmä voi soida eri rytmikaavoissa (laulaja toki tietää, että sävelmä on sama).

Itse asiassa ei ole tarpeen käsitellä kaikkia näitä kuvioita samanvertaisina itsenäisinä rytmeinä. Seitsemäs kuvio (LB BB BB BB) on ilmeisesti tavallisimman tavurytmin muunnos. Nuottinnoskokemukseni perusteella se pikemmin kuvastaa laulajan yksilöllistä laulutapaa ja agogiikkaa, eikä se siis ole itsenäinen rytmikuvio. 
Lippus
Viro
Vatja
Inkeri
Karjala
1. BBBBBBBB
$430(71,4 \%)$
$42(56,6 \%)$
$366(48,8 \%)$
$204(25,7 \%)$
DगDDDगDD

\section{BBBBLLLL $\quad 4(0,7 \%)$}

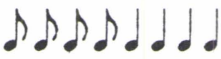

3. BBBBBBBL $48(8,0 \%)$

कDDDSDS.

4. BBBBBBLL $18(3,0 \%)$

$44(5,9 \%) \quad 250(31,5 \%)$

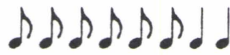

5. BBBLBBBL $14(2,3 \%)$

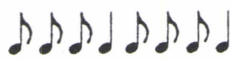

6. BBBLBLBL $3(0,5 \%)$

DDS.D.D.

7. LBBBBBBB $3(0,5 \%)$

- $9 \rho d \rho d \rho d$

8. BBLBBBBB

$24(3,2 \%)$

DDDDDSDD

9. BBLBBBLB

$17(2,3 \%)$

DSDSDSD

10. BBLBBBLL

$17(2,3 \%)$

DDdDSDL.

11. BBLBLBLB

$5(0,7 \%)$

$4(0,5 \%)$

*dगdSdSdD 
Kalevalamittaisen runonlaulun rytmilaeista II

12. (BBLL)BBBB $4(0,7 \%)$

$$
7(0,9 \%) \quad 4(0,5 \%)
$$

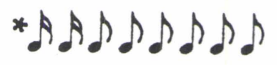

13. (BBLL) LBBB

*ASd)d dod

14. (BBLL)BBLB

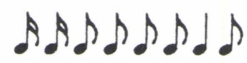

15. BBLLBBLL

$24(4,0 \%)$

$1(1,4 \%)$

$25(3,3 \%)$

$57(7,2 \%)$

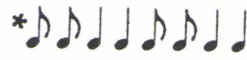

16. (BBLL)LBBL

$76(9,6 \%)$

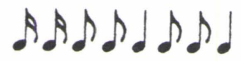

17. LLBBBBLL

$8(10,8 \%) \quad 35(4,7 \%)$

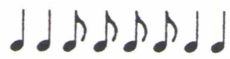

18. LLBBLLBB

$$
6(8,1 \%) \quad 12(1,6 \%)
$$

$\partial \rho \partial \rho \partial \rho \rho$

19. BLBLBLBL

$39(6,5 \%)$

$2(2,7 \%)$

$7(0,9 \%)$

d) dd dd d

20. LBLBLBLB

$24(3,2 \%) \quad 20(2,5 \%)$

d

21. LBLBLBLL

$19(2,4 \%)$

मdddgded

22. LBLLLBLL

$4(0,5 \%)$

ddddd dd.

${ }^{*}$ contractio 
Kuudes kuvio (BL BL BL; 3 virolaista sävelmää) ja yhdestoista kuvio (BB LB LB LB; 4 karjalaista sävelmää) muuntelevat samanlaista sävelmää, runojalkaa on jonkin verran tiivistetty; tällaiset säkeet vaihtelevat toisinaan säännönmukaisten BL- ja LB-säkeiden kanssa (taulukon kohdat 19 ja 20).

Yhtenä kokonaisuutena voitaisiin käsitellä niitä inkeroissävelmiä, joissa ensimmäisen motiivin kuviona on BB LB (8, 9, 10 sekä ne inkeroissävelmät, jotka käyttävät rytmikuviota 11); tässä on huomion keskipisteenä kolmannen tavun pitkä sekä enimmäkseen melko mutkikkaalla melismalla koristeltu sävel, nuottikirjoituksessa se on yleensä kolmen lyhyen pituinen.

Säkeen viimeisen runojalan venyttämisestä virolaisissa sävelmissä (BL - kuvio 3 -; karjalais- ja inkeroissävelmissä LL - kuvio 4), jolla on todennäköisesti kadenssin venyttämisen tehtävä, oli jo puhetta. Samankaltaiseksi ilmiöksi, puolisäkeen merkitsemiseksi, arvioisin 5. rytmikuviota BB BL; se on levinnyt laajalle sekä virolaisiin että karjalaisiin sävelmiin. Mutta voiko myös 15. kuviota BBLL (tunnetaan kaikkialla) ja sen karjalaista muunnelmaa LBLL (kuvio 22) näin selittää, on jo epävarmaa. Viimeisestä rytmistä pitää tietysti sanoa, että sitä ei voi nuotintaa tahtilajiin $3 / 4$. Tässä elementit ryhmittyvät neljäksi pariksi - nopea runojalka (BB) ja hidas runojalka (LL), kolmas jälleen nopea, neljäs hidas. Sen ohella hitaan runojalan pitkät kestot voivat musiikissa jakaantua koruiksi. Tämä ei kuunneltaessa synnytä vaikutelmaa kolmesta tasaveroisesta iskusta, eikä sitä saisi kuviota tulkitessakaan näin hahmottaa (on toinen asia, jos johonkin labajalavalssiin ${ }^{10}$ on ilmestynyt satunnaisesti runonlaulumuotoiset tai sen sukuiset sanat).

Näissä rytmikuvioissa olemme jo joutuneet käyttämään tiivistämisestä termiä contractio, jotta voitaisiin kuvata rytmikuvioita 12 , 13, 14 ja 15. Ehkä olisi paikallaan puhua ainoastaan ensimmäisen runojalan - (BB)BB - eikä koko ensimmäisen motiivin tiivistämisestä (BBLL) -, kuten olen tehnyt. Katson kuitenkin koko motiivin tiivistetyksi sen vuoksi, että se on suhteellisesti itsenäisempi kuvio kuin runojalka; tiivistetystä motiivista on edelleen huomattava lyhyiden (BB) ja pitkien (LL) vastakohtaisuus. Tietysti tässä on kyse vain muodosta. Edellä mainitun tempuksen perusteella on ilmeisesti selvää, miksi emme halua kuvata rytmiä (BBLL)BBBB (kuvio 12) rytmiksi BB LL LL LL; muita kuvioita ei voi kuvailla kahden pääkeston avulla.

Näistä neljästä rytmistä, joilla on tällainen alkumotiivi, on kaksi 
rytmikuviota vakaita ja itsenäisiä. Rytmiä, jossa 2. motiivi koostuu lyhyistä kestoista (BBLL) BB BB on kyllä tavattu Virosta erittäin suppealta alueelta - Valgamaalta Sangasten ja Urvaisten kunnasta -, mutta sävelmätyypit ovat olleet erittäin vakaita, joten sen olemassaoloa ei voi mitenkään epäillä. Seitsemän samarytmistä sävelmää Inkerinmaalta lienee samoin suuri määrä. Karjalasta on suhteellisen hyvin tunnettu melko omalaatuinen ja monimutkainen rytmikuvio (BB LL) LB BL (kuvio 16). Tämän viimeisen toisinnoiksi voisimmekin olettaa kuvion 13 rytmissä olevia lauluja (BBLL) LB BB (viimeinen $L$ on jostain syystä lyhentynyt) mutta myös kuvion 14 rytmissä olevia lauluja (BBLL) BB LB (melisma on siirtynyt) sekä karjalaisten laulujen rytmiä (BBLL) BB BB (4 sävelmää).

Edelleen voisi pohtia sitä, millaiset runoa vastaavat rytmikuviot voisivat perinteen pohjalta olla kiellettyjä. Enemmän kuin neljä pitkää kestoa säkeessä on mahdollista vain kahden laajalti levinneen rytmin yhteensulautuessa (kuvio 21, LL LB LB LL) - rytmiin LB lisätään viimeisen runojalan venytys (kuvio 20 + kuvio 4; kuvio 22 on saman ilmiön toisto eli kuvio 21 + kuvio 15). Nämä ovat siis mielestäni "vääriä" tai runonlauluperinteelle epäluonteenomaisia rytmejä: yhdessä runossa on enemmän kuin neljä pitkää kestoa.

Toinen yleinen pyrkimys on se, että ensimmäinen motiivi on liikkuvampi kuin toinen tai ainakin samanvertainen. Pitempi (sisältää enemmän pitkiä kestoja) se voi olla vain poikkeustapauksissa - kuvio 7, LB BB BB BB, onkin poikkeuksellinen, mutta kuviossa 8, BB LB BB $\mathrm{BB}$, on pitkän nuotin sijassa usein lisätavuja sisältävä melisma: näissä lauluissa on kertosäkeitä ym. tasapainotilanteita synnyttäviä elementtejä. Juuri tästä näkökulmasta voisivat kuviot 12-14 ja 16 olla vääriä, ellei ensimmäinen motiivi muuntuisi tiivistämisen takia lyhyemmäksi kuin toinen.

Yhteenvedoksi voisikin sanoa, että kaikkien mahdollisten rytmikuvioiden syntyä rajoittaa tarve säilyttää liike, tempus. Sen kahden tason (päärytmin ja koristeitten) ilmaisemiseksi, samoin kuin muotoelementtien aseman merkitsemiseksi on lineaarirakenteisissa sävelmissä ainoastaan yksi ja sama sävellinja. Tässä suhteessa runonlaulu poikkeaa funktionaalis-harmonisesta ja metrum-pohjaisesta musiikista, joissa myös yksiäänisenä on tosiasiassa monta linjaa kerrallaan, ja esimerkiksi muodon merkitseminen jakautuu monelle musiikin osatekijälle. 


\section{Runonlaulujen rytmikuvioiden muuttaminen}

Lukija on jo ilmeisesti huomannut, että taulukossa esitetyt rytmikuviot eivät kata kaikkia lauluja. Sanottakoon sananen levinneimmistä rytmivaihteluista, jotta voitaisiin kuvata jäljelle jääneitä lauluja. Toistan vielä kerran, että kaikista nuotinnoksista ei säännöllisen rytmikuvion löytäminen olekaan mahdollista - ainakin jos on yksityinen, rytmiltään erittäin epäsäännöllinen nuotinnos, johon on kirjoitettu vain yksi tai pari erirytmistä sävelmätoistoa ja josta ei ole löydettävissä samankaltaisia toisintoja eikä nykyaikaisia nauhoituksia.

Eräs Inkerinmaalta ja Virosta erittäin usein tavattu erikoisuus on runon kahdeksannen tavun pois jättäminen joko ainoastaan jälkisäkeistä, kaikista tai melkein kaikista säkeistä. Sellaisissa lauluissa osa säkeistä on 7-tavuisia, ja jos niitä täytyy laulaa 8-tavuisina, täytyy pidentää sananloppua, toisissa säkeissä tavu taas jätetään laulamatta: "Kurat sundku suuri saksu, kurat sundku suuri saks"11, "Lehtoa levätäksega, mätästä munijaksee."12 Sitä voi tavata monista edellä kuvailluista rytmikuvioista, ja viimeinen, seitsemäs tavu lauletaan siis aina pitkäksi - inkeroislauluissa esim. BB BB BB L, BB LB BB L, BB LL BB L jne. Edellä kuvattu alkuosaltaan tiivistetty Sangasten ja Urvasten rytmi soikin todellisuudessa kaksisäkeisissä sävelmissä niin, että jälkisäkeen viimeinen tavu "imeytyy": (BB LL) BB BB / (BBLL) BB L. Saman löydämme toisistakin rytmeistä: BB BB LL LL / BB BB LL L, BB BB BB BB / BB BB BB L. Nuotinnoksissa sellaisiin tapauksiin on usein kirjoitettu tauko, joskus pitkän, joskus lyhyen keston jälkeen. On vaikea sanoa, onko runonlaulussa todellista taukoa lainkaan. Pikemminkin siinä on säkeenlopun sesuura venytetyn lopputavun perässä, ja jokainen laulaja esittää sen omalla tavallaan.

Tietyistä lauluista löydämme puolisäkeen toistoa, niin että muodostuu kolmimotiivinen melodiansäe. Sitä tapaa erityisesti inkeroislauluista, muista vähemmän. Rytmikuvioiden kannalta ei näiden sävelmien analysointi anna uutta tietoa; enimmäkseen niissä on yhtäläinen syllabinen rytmi. Inkeroislauluista löydämme myös pitkän säkeen viimeisen runojalan venyttämistä: BB BB BB BB BB LL ("Siso lauloi, lehti lensi, lehti lensi"). 
4a. Soikkola (Launis 1910: 83, nro. 291)

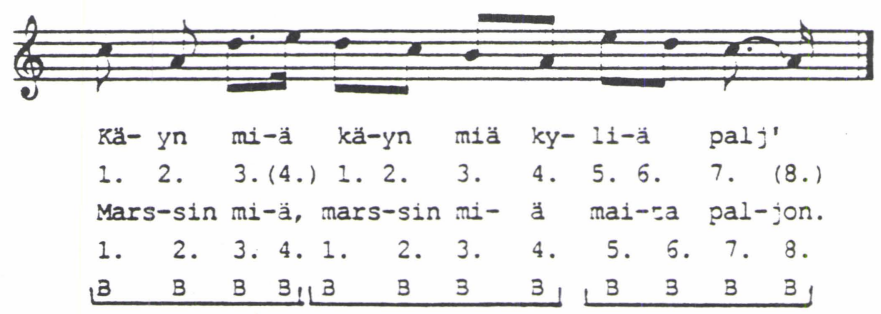

4b. Narvusi (Launis 1910: 89-90, nro. 315)

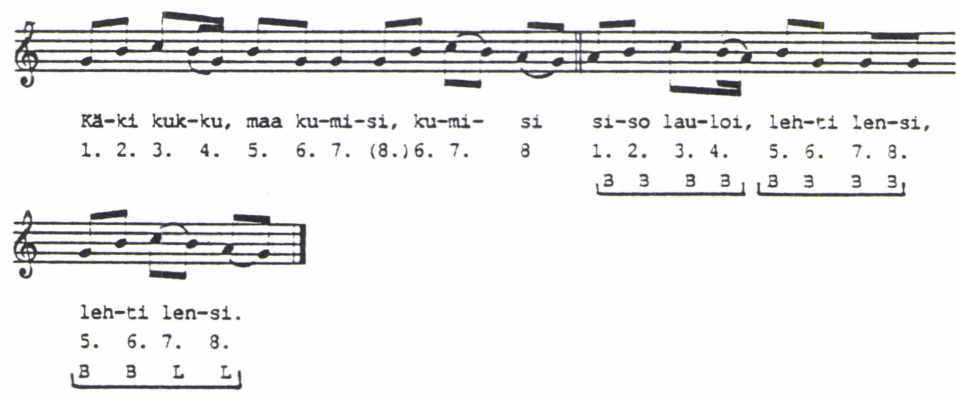

5. Otepää (Tampere 1956-65, V: 123, nro. 83)

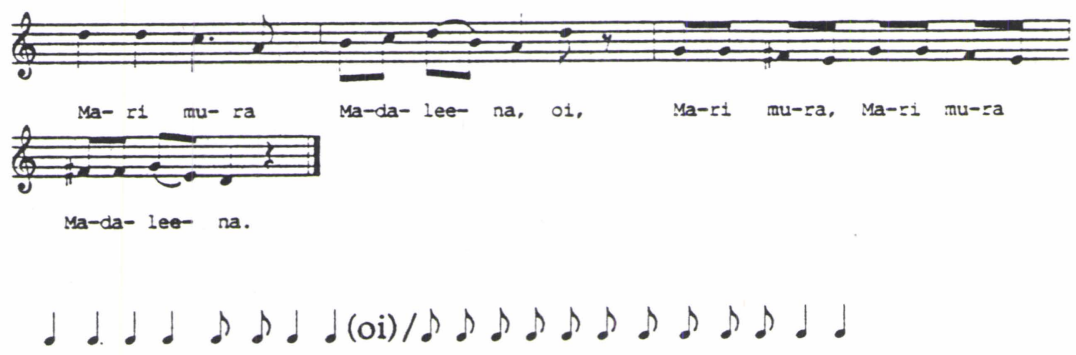

(B B B B), B L L / B B B B B B B B B B L L, dilatatio 
6a. Narvusi (Launis 1910: 255, nro 762.)

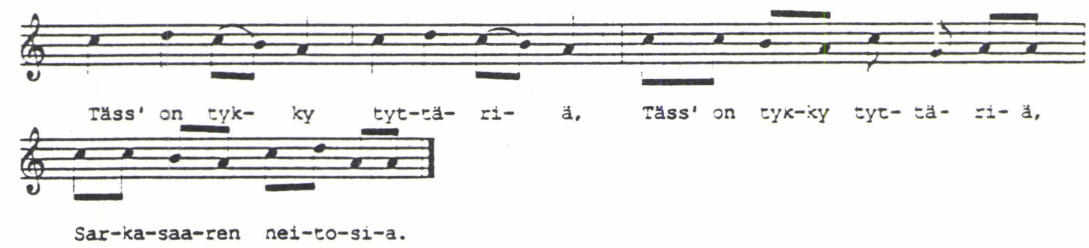

dilatatio

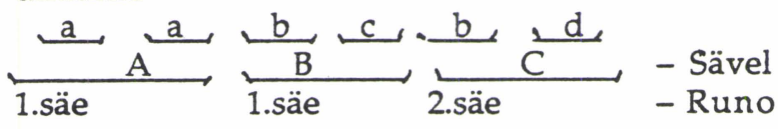

6b. Vändra (Tampere 1956-65, V: 126, nro. 86.)

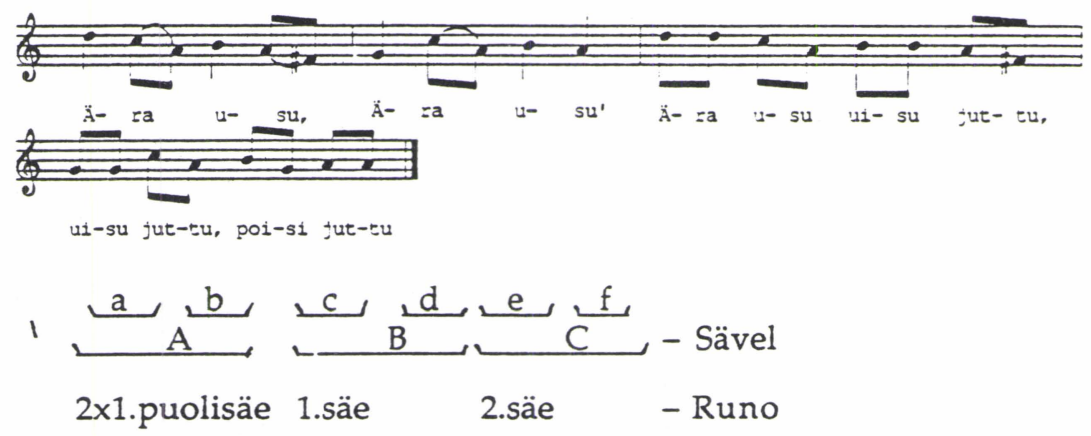

7a. Karjalan kannas ? (Launis 1930: 251, nro. 699.)

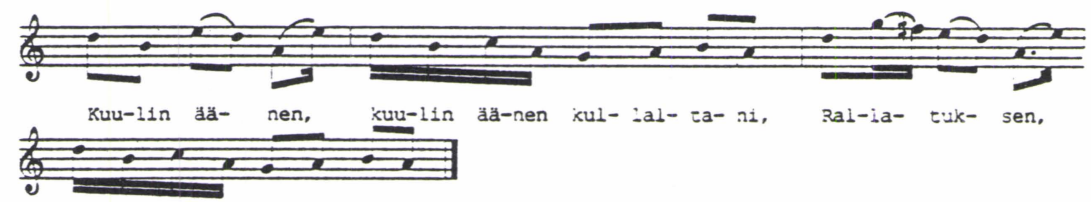

Ral-la- tuk-sen rau-kal-ca-ni.

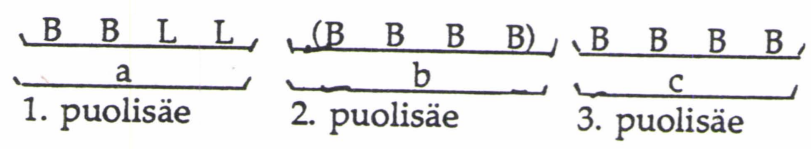

* koriste

tai

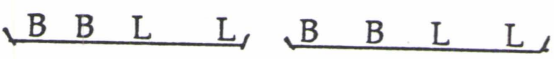

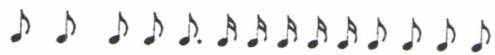


7b. Tyrö (Launis 1910: 81, nro. 281 ja Launis 1910: 55, nro 191.)
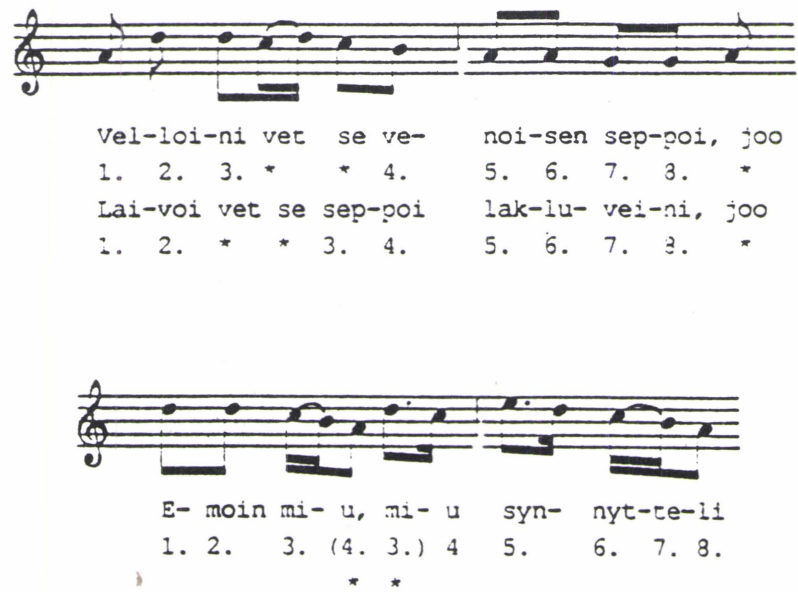

Edellä tuli jo sanotuksi, että joissakin sävelmissä nopea, tiivistetty säe ja normaali säe yhdistetään, samoin normaalin rytmikuvion rinnalla voi olla keskitempon suhteen hidas, venytetty tai laajennettu säe. Viron aineistossa Herbert Tampere on yhdistänyt semmoisiin lauluihin (hidas alku ja nopea loppuosa, tunnetuin tästä ryhmästä on hänen mainitsemansa "Ketra, Liisu"; 1965: 64) venäläisen kansanmusiikin mahdollisen vaikutuksen. Aineistossamme ei ole hidas-nopea -vastakohtaisiin lauluihin lisätty metronomilukemaa, enkä ole löytänyt näistä nauhoituksia. Niinpä on vaikea sanoa, onko tässä kysymys ensimmäisen osan hidastamisesta keskitempon suhteen tai toisen osan pikapuheesta. Melkein kaikkiin nuotinnoksiin, sekä Tamperen että Launiksen teoksissa, on hitaassa osassa otettu tavun kestoksi neljäsosanuotti, kuin kyseessä olisi hidastaminen, mutta edellä mainitussa artikkelissa Tampere mainitsee toisen osan olevan pikapuhetta. Selkeämpiä ovat laulut, joissa ensimmäisessä osassa on laajennettu ainoastaan yhtä puolisäettä ja toinen on normaalitempossa (nuotinnoksessa tavua vastaa kahdeksasosanuotti), toisessa osassa on toistettu ensimmäistä puolisäettä, niin että syntyy esimerkin 5 mukainen rakenne.

Samanlainen jälkimotiivi sitoo säkeet, ja sen kautta voidaan arvioida sekä tempoa että esitystapaa.

Esimerkeistä voi havaita, että hitaampi ja nopeampi puolisko halutaan säilyttää tasavertaisina; on samantekevää, leikitelläänkö 
puolisäkeellä vai kokosäkeellä (viimeisessä tapauksessa nopea osa koostuu kahdesta runontoistosta). On lauluja, joissa hitaalla ja nopealla osalla ei ole musiikillista eroa - samalla sävelmällä, nuotteja kahden tavun välille jakaen runo lauletaan kaksi kertaa nopeammin. Tämä on todellisuudessa enemmänkin koristelua, musiikillisesti samanvertaista kuin lisätavujen kiilaaminen runoon, eikä rakenteen tiivistämistä (esim. 6).

Samoin voimme selittää sekä koristelulla että tiivistämisellä joitakin karjalaisia sävelmiä, joissa ensimmäinen puolisäe toistuu tiivistettynä, niin että kolme puolisäettä mahtuu musiikillisesti kahteen samanmittaiseen puoliskoon - BB LL (BB BB) BB BB tai BB LL BB LL (viimeisessä puolisäkeessä olisi siis kaikki nuotit koristeltu). Miksi yleensä vertailla runon rakenteellisen osan toistoa koristeluun? Erityisesti inkerois- mutta myös karjalaislauluissa on tapana tuoda melismoihin lisätavuja pitkän nuotin aikana (vet, vet, en, oi jne.). Samaan tarkoitukseen otetaan joskus myös sanoja samasta säkeestä, niin että runojalan toiston ei tarvitse merkitä musiikillisen rakenteen jonkin elementin toistoa (esim. 7).

\section{Rytmikuvion koristelu runolaulussa}

Päätteeksi analysoimme joitakin esimerkkejä kaavanmukaisen rytmikuvion koristelusta, equipollentiasta. Juuri tämän prosessin kuluessa rytmikuvionsa puolesta samankaltaiset laulut muuttuvat tunnistamattoman erilaisiksi, tässä kukoistaa laulajain omaperäisyys. Sekä pitkiä että lyhyitä nuotteja voi koristella. Virolaiset laulajat eivät erityisemmin harrasta koristelua lukuun ottamatta Pohjois-Viron keinulaulujen esityksiä (esim. 8).

Eniten sävelmiä koristellaan Inkerinmaalla, ja siitä näkyy jossakin määrin venäläisen perinteen vaikutus (samoin kuin venäjänkieliset kertosäesanat muinaisaikaisessa itämerensuomalaisessa laulussa). Pisimmät melismat löydämme sekä inkerois- että karjalaislauluissa runon keskimmäisiltä pitkiltä nuoteilta (3. tai 5. tavu); muiden elementtien koristelu rajoittuu viereisen sävelasteen lisäämiseen lomasävel-, sivu- tms. koristesäveleksi, kvinttihypyn korusävelenä on enimmäkseen tietysti terssi. (esim. 9.)

Joskus sävelmiä analysoitaessa on tarpeen päättää, mikä melisman sävelistä on pääsävel, mikä korusävel. Se on helppo tehdä, jos 
meillä on koottuna joukko sävelmätoisintoja, jotkin koristeltuja, jotkin puolestaan toistensa tarkkoja ja koristelemattomia toisintoja. Nykyinen aineistomme sisältää enimmäkseen vain 1-2 sävelmätoisintoa. Päätöksenteossa auttavat variantit, mutta erityisesti melodisen liikkeen yleinen logiikka.

Sävelmien sävelikköä eriteltyämme voimme väittää, että runolaulujen sävelmissä käytetään tavallisesti kaikkia äärisävelten välisiä asteita, "aukko" laulun sävelrivissä on poikkeus (ainoastaan Viron sävelmistä on tiedot julkaistu - Lippus 1988: 97-105). Se pitäisi ottaa huomioon myös riisuttaessa sävelmää koristuskuvioista. Saman periaatteen mukaisesti pyritään välttämään hyppyjä, joita seuraava melodian liike ei täytä tai tasapainota, ja useamman kuin kahden tai kolmen saman sävelen perättäistä toistoa. Kaikkia näitä ilmiöitä sävelmistä toki tavataan mutta suhteellisen harvoin. Kuten voi havaita, tässä on puhe vain erittäin yleisistä melodiankulun periaatteista, jotka ovat lineaariselle musiikille laajalti ominaisia.

Olen sävelmiä pelkistäessäni valinnut rakenne-elementin sävelkorkeudeksi aina ryhmän ensimmäisen sävelen ja samalla seurannut, voisiko muodostaa sääntöä, milloin jossakin tapauksessa suositaan jotain säveltä, samoin sitä, kuinka monessa tapauksessa näin syntyy "virhe". Tarkkaa tilastoa minulla ei tästä ole, mutta likimäärin voisi sanoa, että "virheitä" (koska ei ole sääntöjä, ei myöskään "virheiksi" arvioimiselle ole varmaa pohjaa) tulisi alle $10 \%$. Erittäin paljon (mahdolliseti jopa noin $40 \%$ ) on tapauksia, että koristekuvioita eri tavoin tulkitessamme saisimme useita samanarvoisia variantteja. Seuraava esimerkki kuvaa joitakin semmoisia tapauksia. On myös paljon sävelmiä, joita aina esitetään samankaltaisella melismalla, niin että todellista peruskestoista säveltä ei olekaan ja sävelmän kahdeksannuottinen normaalimuoto on vain abstraktio (esim. 10).

\section{Päätteeksi}

Tässä artikkelissa emme voi tarkastella sitä, kuinka kaikki nämä rytmikuviot ovat lauluohjelmistoon levinneet. Se olisi erittäin kiinnostava aihe, mutta edellä esitetyt levikkiluvut ainoastaan neljästä eri kansasta tai kielialueesta ovat liian yleisiä, jotta voitaisiin tuoda esille edes olennaisia yhteyksiä. Rytmikuvioiden osalta ovat Pohjois- ja Etelä-Viron repertoaarit jopa erilaisempia kuin Koillis-Viron ja Vatjan 
Lippus

8. Kuusalu (Tampere 1956-65, II: 128, Anro. 12.)
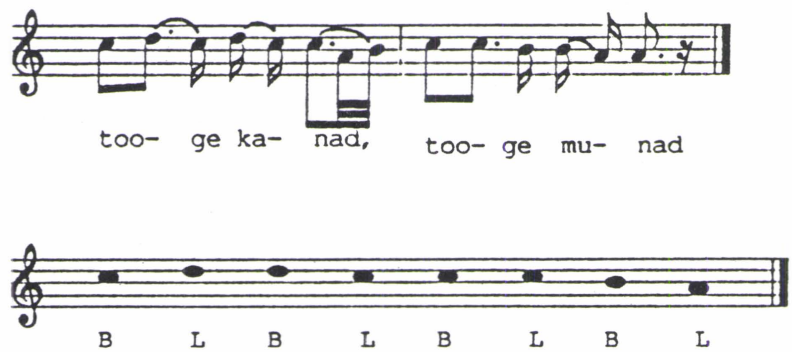

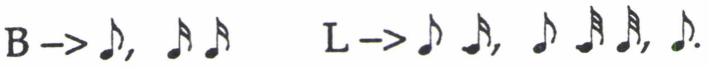

9. Soikkola (Launis 1910:95, nro.331.)
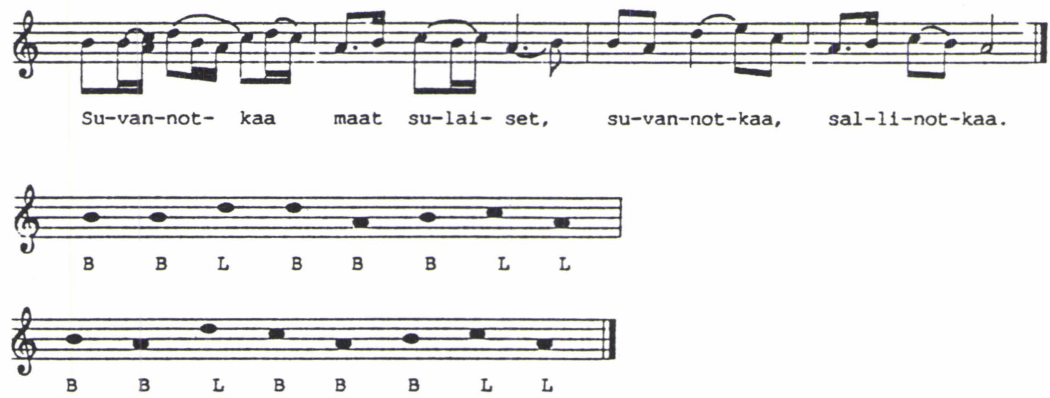

$$
B \rightarrow D, A A, D, A \quad L \rightarrow D A A D, D A A, D D, d D, d D, d
$$

10a. Kuusalu (Tampere 1956-65, II: 295.)

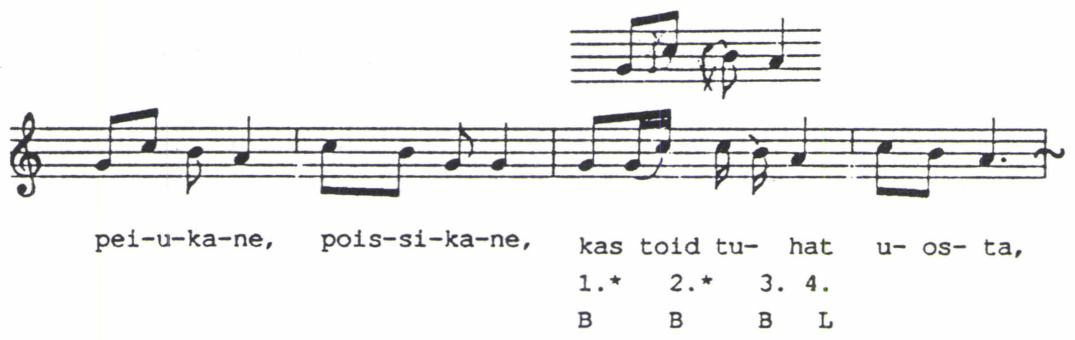


10b. (Launis, 1930: 162, nro. 461.)
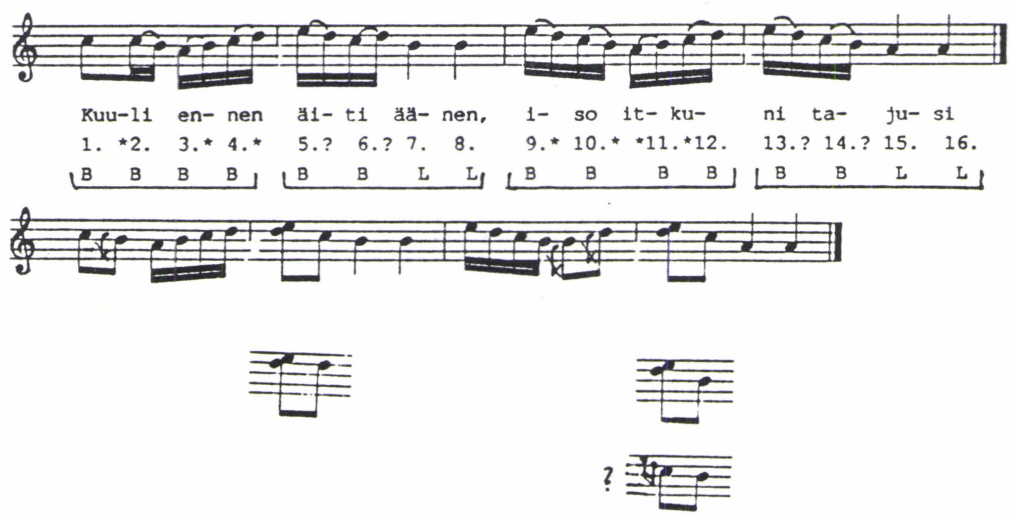

aineistot. Viimeksimainittujen alueiden samankaltaisuus, samoin kuin vatjalaisen ja inkeriläisen sekä inkeroiskarjalaisen rytmiikan yhtäläisyys on tietenkin luonnollista. Merkittävimmäksi arvioisin sitä, että monet Karjalasta tavatut kuviot ovat joko ainoastaan tai enimmäkseen tunnettuja juuri Etelä-Virossa, tarkemmin Vørun- ja Valgamaalla. Sellaisten ilmiöiden selvittämiseksi täytyisi tehdä eri tutkimus (alkumotiiviltaan tiivistetyt rytmit - kuviot 12-16 -, suomalaiseen tyyliin venytetyt loput - rytmikuvio 4).

Lopuksi palaamme runolaulun luota takaisin globaalisten ongelmien pariin. Tämä on yksi esimerkki (enkä tiedä, miten paljon tällaisia esimerkkejä nykymaailmasta löytyy) siitä, miten 1100-luvun lopulla kehitetty teoreettinen rytmijärjestelmä toimii, kun erotetaan ainoastaan kaksi kestoa ja kun kulmakiveksi asetetaan kestojen likiarvoinen yhdenvertaisuus:

tempus $\rightarrow$ longa $\rightarrow$ longa + brevis $->2$ breve $\rightarrow 3$ breve

Tällaisten vastakohtien olemassaolo tekee kestojen tarkat mekaaniset suhteet mahdottomiksi - tämmöistä tilannetta on muuten nykyaikaisen musiikkikoulutuksen saaneen ihmisen erittäin vaikea kuvitella.

Luonnollisesti sekä runonlaulun teksti että musiikillinen rytmiikka ovat tiiviisti sidoksissa itämerensuomalaiseen prosodiaan, ennen kaikkea siksi, että prosodisen ajattelun yksikkönä on tavupari; toiseksi siksi, että myös lyhyet tavut ovat painollisia eikä pitkän ja lyhyen sekä painollisen ja painottoman vaihtelun tarvitse käydä tasatahtia. Mie- 
lestäni runonlaulussa ei y̧leensä ole mahdollista muodostaa täysin aitoa kolmitavuista runojalkaa: Sen vuoksi jotkin näennäisesti kolmijakoiset rytmikuviot:

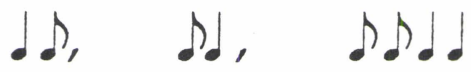

kävisivät mahdollisesti esimerkiksi siitä, miten myöhemmin (kun teoreettiseen ajatteluun oli kotiutunut seuraava keston jakautumisen taso, semibrevis) näitä kolmiosaisiksi kuvailtuja keskiaikaisia rytmejä voisi tulkita.

\section{Lähteet}

Eek, Arvo (1987), Kvantiteet ja rõhk eesti keeles (II). Seisukohavõtt. Keel ja Kirjandus, nro 3-6, s. 153-160, 205-213, 277-284, 344-352.

Lauguaste, Eduard (1977), Eesti rahvaluule. Tallinn.

Launis, Armas (1910), Inkerin runosävelmät. Suomen kansan sävelmiä IV, Runosävelmiä I. Helsinki.

(1930), Karjalan runosävelmät. Suomen kansan sävelmiä IV, Runosävelmiä II. Helsinki.

Lehiste, Ilse (1973), The well-formedness of an Estonian folk song line. Baltic Literature and Linguistics, pp. 135-139.

Lippus, Urve (1984), Estonski runitseski napev i metodika ego issledovanija. Dissertatsija na soisk. n. st. kand. isk. Moskva.

(1988), Regiviiside heliread. Muusikalisi lehekülgi V. Tallinn, s. 88127.

(1990), Kalevalamittaisen runonlaulun rytmilait. Etnomusikologian vuosikirja 1989, s. 96-111.

Rüütel, Ingrid (1977), Vadja rahvamuusika tüpoloogia ja stiilid. Soome-ugri rahvaste muusikapärandist. Koost. I. Rüütel, Tallinn, s. 216-273.

Tampere, Herbert (1956-65), Eesti rahvalaule viisidega I-V. Tallinn. (1965), Eesti regivärsilise rahvalaulu meloodika stiilitüübid. Etnograafiamuuseumi aastaraamat 20. Tartu, s. 50-66.

\footnotetext{
1 Artikkelin ensimmäinen osa on julkaistu Etnomusikologian vuosikirjassa 1989-90, s. $96-111$, ja siinä on esitetty kalevalamittaisen laulun rytmianalyysin teoreettiset perusteet.

2 Guido Arezzolainen tai Aretinus (n. 992 - n. 1050), italialainen musiikinopettaja ja solmisaation kehittäjä.

$3 \mathrm{KM}$ RO = F.R. Kreutzwaldi nimelise Kirjandusmuuseumi Rahvaluule Osakond (Kreutzwaldin kirjallisuusmuseon kansanrunouden osasto).
} 
4 Suomalaisen Kirjallisuuden Seura.

5 Eesti Vabariigi Teaduste Akadeemia Keele ja Kirjanduse Instituut (Viron tiedeakatemian kielen ja kirjallisuuden laitos).

6 Vir. 'sai se vene veistetyksi, kaavituksi laivan kansi'.

7 Vir. 'jos ei kanna niin kaatukoon'.

8 Vir. 'pelkäävät kullat kuluvansa'.

9 Vir. 'hovissa on hopeasepät, tarhassa rahantakojat'.

10 Labajalavalss = hidastempoinen, 3/4-tahtilajissa kulkeva virolainen kansantanssi, kolmijakoisen saksalaisen valssin toisinto. Labajalavalssille (sananmuk. jalkaterävalssille) on ominaista 1. tahdinosan voimakas korostus; myös 8 . tahdin 2 . isku voi olla painollinen.

11 Vir. 'piru pakottakoon suuria herroja'

12 Inker. 'lehtoa levähtääksensä, mätästä muniaksensa' 